\title{
Cellular Uptake and Cell-Associated Activity of Third Generation Cephalosporins
}

\author{
RICHARD F. JACOBS, JOSEPH W. THOMPSON, DEBORAH P. KIEL, AND DIANNE JOHNSON
}

University of Arkansas for Medical Sciences, and Arkansas Children's Hospital, Little Rock, Arkansas 72202

\begin{abstract}
The ability of the third generation cephalosporins to penetrate human polymorphonuclear leukocytes (PMNs) and their antibacterial activity against cell-associated Staphylococcus aureus (SA) and Haemophilus influenzae, type b (Hib) were studied. Utilizing radioactive uptake experiments, the cellular to extracellular concentration ratios were determined to be less than one for all cephalosporins at 10 and 120 min: cefotaxime $(0.08 \pm$ $0.02,0.34 \pm 0.08)$, ceftizoxime $(0.21 \pm 0.11,0.52 \pm 0.18)$, ceftriaxone $(0.12 \pm 0.04,0.38 \pm 0.23)$, and $\mathrm{N}$-formimidoyl thienamycin $(0.18 \pm 0.09,0.33 \pm 0.14)$. Third generation cephalosporins were similar to penicillin in their exclusion from PMNs. The killing of cell-associated SA and Hib were evaluated in a preopsonized cell-associated bacterial assay with radiolabelled $\mathrm{SA} / \mathrm{Hib}(\mathrm{cfu} / \mathrm{cpm})$ comparing activity of PMNs + antibiotics to the PMN cell control (no antibiotics) at $0.5,2$, and $4 \mathrm{~h}$. PMNs alone killed $\leq 0.5 \mathrm{log}$ $\mathrm{SA} / \mathrm{Hib}$ over $4 \mathrm{~h}$. Clindamycin killed significantly more SA $(p<0.01)$ than all other antibiotics; nafcillin killed significantly fewer SA $(p<0.05)$ than all other antibiotics. Although each third generation cephalosporin showed good activity against cell-associated Hib, chloramphenicol had a significantly greater effect $(p<0.05)$. $\mathrm{N}$-formimidoyl thienamycin demonstrated good activity only after the concentration was increased in vitro to $8 \mu \mathrm{g} / \mathrm{ml}$. Although cellular penetration of antibiotics may be important in the eradication of cell-associated pathogens, the overall cellular activity would appear to be multifactorial. (Pediatr Res 20:909-912, 1986)
\end{abstract}

\section{Abbreviations}

SA, Staphylococcus aureus

Hib, Haemophilus influenzae, type b

cfu, colony forming unit

cpm, counts per minute

HBSS, Hanks' balanced salt solution

GBSS, Geys balanced salt solution

PMN, polymorphonuclear leukocytes

MIC, minimum inhibitory concentration

MBC, minimum bactericidal concentration

$\mathrm{C} / \mathbf{E}$, cellular to extracellular concentration ratio

SpAc, specific activity

Bacterial pathogens that are capable of survival and replication intracellularly are a significant cause of human infections; path-

Received September 17, 1985; accepted May 7, 1986

Correspondence and reprint requests to Dr. Richard F. Jacobs, Department of Pediatrics, Arkansas Children's Hospital, 804 Wolfe Street, Little Rock, AR 72202.

Supported in part by the Chancellor's Grant-University of Arkansas for Medical Sciences and a grant from the UpJohn Company, Kalamazoo, MI. R.F.J. is an EL Trudeau Scholar of the American Lung Association. ogens that have been demonstrated to be "cell-associated" in human disease and experimental infections may also be clinically significant (1-4). If these pathogens are capable of intracellular survival, they may evade killing by antibiotics that do not enter phagocytic cells (5-9).

The newer $\beta$-lactam antibiotics have been shown to have marked activity against Hib and good (although variable) activity against may strains of SA (10). We evaluated the ability of these antibiotics to penetrate PMNs and kill cell-associated SA and Hib.

\section{METHODS}

PMN isolation. PMNs were obtained from whole blood of adult donors free of infection and antibiotics. Heparinized (20 $\mathrm{U} / \mathrm{ml}$ ) blood was added to dextran (Macrodex, $6 \% \mathrm{w} / \mathrm{v}$, in saline, Pharmacia Laboratories, Piscataway, $\mathrm{NJ}$ ) at a ratio of $5 \mathrm{ml}$ blood: $1 \mathrm{ml}$ dextran and was allowed to sediment in an upright position until the erythrocytes settled to $50 \%$ of the total volume. The harvested leukocyte-rich-plasma supernate was washed in HBSS without $\mathrm{Ca}^{++}$and $\mathrm{Mg}^{++}$(Grand Island Biological Co, Gibco; Grand Island, NY) by centrifugation at $300 \times g$ for $7 \mathrm{~min}$. The cell button was incubated in $0.84 \% \mathrm{NH}_{4} \mathrm{Cl}$ at $37^{\circ} \mathrm{C} \times 5 \mathrm{~min}$ to lyse retained erythrocytes and washed in HBSS at $300 \times g$ for 7 min. The PMN fraction was isolated by centrifugation of the leukocyte button resuspended in HBSS at $500 \times g$ for $30 \mathrm{~min}$ over Ficoll-Hypaque, specific gravity 1.077 (Sigma Chemical Co., St. Louis, MO). The PMNs were washed twice in HBSS at 300 $\times g$ for $7 \mathrm{~min}$, resuspended in RPMI 1640 (Gibco) and counted in a hemacytometer. Viability as determined by trypan blue dye exclusion was consistently $>97 \%$.

Uptake of antibiotics by PMNs. PMN penetration by cefotaxime, ceftizoxime, ceftriaxone, and $\mathrm{N}$-formimidoyl thienamycin was assayed as previously described $(5,6,11)$. Each reaction tube contained $1 \mathrm{ml}$ of $5 \times 10^{6}$ PMN in RPMI 1640 with $10 \%$ fetal calf serum (Gibco) and $100 \mu$ l of one of the following in RPMI 1640 yielding a final concentration as listed: $8 \mu \mathrm{Ci} / \mathrm{mI}\left[{ }^{3} \mathrm{H}\right] \mathrm{H}_{2} \mathrm{O}$ (SpAc- $100 \mu \mathrm{Ci} / \mathrm{ml}$, New England Nuclear, Boston, MA), 44 $\mu \mathrm{Ci} / \mathrm{ml} \mathrm{Na}_{2}{ }^{35} \mathrm{SO}_{4}(\mathrm{SpAc}-500 \mu \mathrm{Ci} / \mathrm{ml}$, New England Nuclear), $5 \mu \mathrm{Ci} / \mathrm{ml}\left[{ }^{14} \mathrm{C}\right]$ cefotaxime (SpAc- $100 \mu \mathrm{Ci} / \mathrm{ml}$, Hoechst, Frankfort, Germany), $5 \mu \mathrm{Ci} / \mathrm{ml}\left[{ }^{14} \mathrm{C}\right]$ ceftizoxime (SpAc-17.2 mCi/ mmol, Smith, Kline, and French, Philadelphia, PA), $5 \mu \mathrm{Ci} / \mathrm{ml}$ $\left[{ }^{14} \mathrm{C}\right]$ ceftriaxone $(\mathrm{SpAc}-100 \mu \mathrm{Ci} / \mathrm{ml}$, Hoffman-LaRoche, Nutley, $\mathrm{NJ}$ ), $5 \mu \mathrm{Ci} / \mathrm{ml} \mathrm{N}$-formimidoyl thienamycin (SpAc-0.4 $\mathrm{mCi} / 29.4 \mathrm{mg}$, Merck, Sharpe, and Dohme, Rahway, NJ), $5 \mu \mathrm{Ci} /$ $\mathrm{ml}\left[{ }^{3} \mathrm{H}\right]$ clindamycin $(\mathrm{SpAc}-50 \mu \mathrm{Ci} / \mathrm{ml}$, UpJohn Co, Kalamazoo, MI), or $5 \mu \mathrm{Ci} / \mathrm{ml}\left[{ }^{14} \mathrm{C}\right]$ penicillin $(\mathrm{SpAc}-25 \mu \mathrm{Ci} / \mathrm{ml}$, New England Nuclear). The reaction mixtures were incubated in a $37^{\circ} \mathrm{C}$ shaking water bath at $200 \mathrm{rpm}$. At 10 and $120 \mathrm{~min}$ a $500-$ $\mu \mathrm{l}$ aliquot of each was removed, layered over $1 \mathrm{ml}$ inert silicone oil (Versilube, General Electric Co, Schenectady, NY), and centrifuged at $10,000 \times g$ for $2 \mathrm{~min}$ in a microcentrifuge (Eppendorf, Brinkman Electronics, Westburg, NY). The radioactivity of the 
PMN pellet and a $100-\mu 1$ aliquot of the supernate was measured in $10 \mathrm{ml}$ Aquasol-2 (New England Nuclear) using a scintillation spectrometer (Beckman Instruments, Fullerton, CA). The total and extracellular water content of the PMN pellet was determined by dividing the $\mathrm{cpm}$ in the PMN pellet by the cpm in the known volume of supernate for $\left[{ }^{3} \mathrm{H}\right] \mathrm{H}_{2} \mathrm{O}$ and $\mathrm{Na}_{2}{ }^{35} \mathrm{So}_{4}$, respectively. The extracellular water content was consistently $<10 \%$ of the total water content. The cellular water content of the PMN pellet was determined by subtracting the extracellular water content from the total water content of the PMN pellet. The $\mathrm{C} /$ $\mathrm{E}$ of the antibiotics was determined as previously described (5).

$M I C / M B C$ determination. The MIC/MBC values for the antibiotics against an ATCC 25923 strain of SA (Difco Laboratories, Detroit, MI) and a clinical isolate of Hib were determined by the tube dilution method using a standard inoculum (12).

Effects of antibiotics on cell-associated SA and Hib. The antimicrobial activity of each antibiotic against cell-associated SA and $\mathrm{Hib}$ was assayed as previously described $(5,6,11)$. To prepare radioactive bacterial cultures, $10 \mathrm{ml}$ of RPMI 1640 without leucine (Gibco) plus $2.5 \mu \mathrm{Ci}\left[{ }^{14} \mathrm{C}\right]$ leucine $(\mathrm{SpAc}-344 \mathrm{mCi} /$ mmol, New England Nuclear) was inoculated with $100 \mu \mathrm{l}$ of a fresh SA stock culture (tryptic soy broth) and placed in a shaking $37^{\circ} \mathrm{C}$ water bath at $200 \mathrm{rpm} \times 21 \mathrm{~h}$. Radioactive Hib was grown from four, 1-day-old, chocolate agar colonies placed in $20 \mathrm{ml}$ Catlin's media without leucine (13) and $12 \mu \mathrm{Ci}\left[{ }^{14} \mathrm{C}\right]$ leucine in a $5 \% \mathrm{CO}_{2}$ incubator $\times 24 \mathrm{~h}$. Both the $\mathrm{SA}$ and $\mathrm{Hib}$ cultures were washed twice in cold $\left(4^{\circ} \mathrm{C}\right)$, GBSS (Gibco) by centrifugation at $1900 \times g$ for $15 \mathrm{~min}$. The concentration of SA was adjusted to an OD of 0.15 at $490 \mathrm{~nm}$ to yield $2 \times 10^{7} \mathrm{cfu} / \mathrm{ml}$. The Hib washed button was resuspended in $12.5 \mathrm{ml}$ RPMI 1640 to yield an inoculum of $2 \times 10^{9} \mathrm{cfu} / \mathrm{ml}$.

Reaction tubes for each antibiotic studied and an antibioticfree cell control (PMNs + bacteria without antibiotics) contained $1.4 \mathrm{ml}$ bacteria (SA: $2 \times 10^{7} \mathrm{cfu} / \mathrm{ml}$ or Hib: $\left.2 \times 10^{9} \mathrm{cfu} / \mathrm{ml}\right), 1$ $\mathrm{ml}$ of $18 \times 10^{6} / \mathrm{ml} \mathrm{PMN}$, and $0.6 \mathrm{ml}$ serum. The reaction mixtures were incubated in a $37^{\circ} \mathrm{C}$ shaking water bath at 200 $\mathrm{rpm} \times 30 \mathrm{~min}$. Following this incubation of bacteria and PMNs, extracellular organisms were removed by the addition of $10 \mathrm{U} /$ $\mathrm{ml}$ lysostaphin $($ Sigma $) \times 10 \mathrm{~min}$ to the reaction tubes contained SA and by differential centrifugation of the reaction tubes containing $\mathrm{Hib}(5)$. The PMN-bacteria reaction mixtures were resuspended in $3 \mathrm{ml}$ RPMI $1640+10 \%$ fetal calf serum with aliquots containing the described final concentrations of antibiotics or media + serum alone (cell control). The final concentrations of antibiotics used in the reaction mixtures were equal to or exceeded the bacterial MIC/MBC. The concentrations were: $\mathrm{SA}-4 \mu \mathrm{g} / \mathrm{ml}$, nafcillin; $2 \mu \mathrm{g} / \mathrm{ml}$, clindamycin; $1 \mu \mathrm{g} / \mathrm{ml}$, gentamicin; $2 \mu \mathrm{g} / \mathrm{ml}$, cefotaxime; $2 \mu \mathrm{g} / \mathrm{ml}$, ceftizoxime; $2 \mu \mathrm{g} / \mathrm{ml}$, ceftriaxone; and $1 \mu \mathrm{g} / \mathrm{ml}$, N-formimidoyl thienamycin; Hib-8 $\mu \mathrm{g} / \mathrm{ml}$, ampicillin; 2 and $4 \mu \mathrm{g} / \mathrm{ml}$, chloramphenicol; $0.5 \mu \mathrm{g} / \mathrm{ml}$, cefotaxime; $0.5 \mu \mathrm{g} / \mathrm{ml}$, ceftizoxime; $0.5 \mu \mathrm{g} / \mathrm{ml}$, ceftriaxone; 2 and $8 \mu \mathrm{g} / \mathrm{ml}, \mathrm{N}$-formimidoyl thienamycin. The reaction mixture was incubated in a $37^{\circ} \mathrm{C}$ shaking water bath at $200 \mathrm{rpm}$. At 30 $\min , 2 \mathrm{~h}$, and $4 \mathrm{~h}, 1-\mathrm{ml}$ aliquots were removed and centrifuged at $300 \times g$ for $7 \mathrm{~min}$. A growth control (organisms without cells or antibiotics) was assayed in parallel to the above variables. During the phagocytic incubation, the growth control contained $1 \mathrm{ml}$ RPMI 1640, $1 \mathrm{ml}$ bacterial inoculum, and $0.6 \mathrm{ml}$ serum. The growth control was centrifuged at $1900 \times g$ for 2 min and resuspended in $3 \mathrm{ml}$ RPMI $1640+10 \%$ fetal calf serum for the remainder of the experiment. To induce cell lysis, $1 \mathrm{ml}$ of $0.2 \%$ Triton X-100 (Sigma) was added to all reaction tubes containing PMNs, and serial dilutions were made in GBSS. Cell lysates containing SA were spread on tryptic soy agar and incubated overnight at $37^{\circ} \mathrm{C}$. Cell lysates containing Hib were spread on chocolate agar and incubated overnight in a $37^{\circ} \mathrm{C}, 5 \% \mathrm{CO}_{2}$ incubator. A $0.4-\mathrm{ml}$ aliquot of the lysed cell suspensions and growth control was counted in $10 \mathrm{ml}$ Aquasol- 2 on the scintillation spectrometer. The bacterial cfu and $\mathrm{cpm}$ were enumerated the following day.
The cfu/cpm ratios of cell-associated $\mathrm{SA} / \mathrm{Hib}$ were compared between reaction mixtures containing antibiotics and parallel mixtures containing PMNs without antibiotics (cell control). The results were calculated as a fraction survival (percent) relative to this antibiotic-free cell control at each time point $(5,6,14)$.

Statistics. Data are expressed as the mean \pm SD. The significance of differences between means was determined by the Student's $t$ test (15).

\section{RESULTS}

Uptake of antibiotics by PMNs. The mean $\pm 1 \mathrm{SD}$ for the cellular to extracellular concentration ratios with PMNs are shown in Table 1. Penicillin was excluded from PMNs with a C/ $E$ ratio of less than one $(0.29 \pm 0.05$ at $10 \mathrm{~min}, 0.58 \pm 0.16$ at $120 \mathrm{~min}$ ). In contrast, clindamycin was concentrated within $\mathrm{PMNs}$ with $\mathrm{C} / \mathrm{E}$ ratios of $2.95 \pm 0.64$ and $3.39 \pm 1.04$ at 10 and $120 \mathrm{~min}$, respectively. The $\beta$-lactam antibiotics, cefotaxime, ceftizoxime, ceftriaxone, and $\mathrm{N}$-formimidoyl thienamycin were similar to penicillin with $\mathrm{C} / \mathrm{E}$ ratios always less than one. The clindamycin $\mathrm{C} / \mathrm{E}$ ratio was significantly greater than the other antibiotics at both time points $(p<0.001)$. Although ceftizoxime seemed to have better penetration than other newer $\beta$-lactams, no significant differences were found. The $C / E$ ratios were consistent and no effect on PMNs was seen at the completion of the assay due to: 1) PMN clumping--phase contrast microscopy, 2) PMN viability - trypan blue dye exclusion, or 3) a change in the extracellular or total water content of the PMN pellet on intraassay analysis $(p>0.05)$.

$M I C / M B C$ determination. The MIC/MBC values of the study bacteria used in the cell-associated killing assays are shown in Table 2. A marked difference in the susceptibility of the strain of SA against $\mathrm{N}$-formimidoyl thienamycin was found when compared to the other $\beta$-lactam antibiotics. This is in contrast to an increased MIC/MBC of N-formimidoyl thienamycin for the strain of $\mathrm{Hib}$ ( $\beta$-lactamase negative).

Table 1. Cellular/extracellular concentration ratios versus time in PMNs

\begin{tabular}{lll}
\hline \multirow{2}{*}{\multicolumn{1}{c}{ Drug $(n=6)$}} & \multicolumn{2}{c}{$\mathrm{C} / \mathrm{E}^{*}$} \\
\cline { 2 - 3 } & \multicolumn{1}{c}{$10 \mathrm{~min}$} & \multicolumn{1}{c}{$120 \mathrm{~min}$} \\
\hline Penicillin & $0.29 \pm 0.05$ & $0.58 \pm 0.16$ \\
Clindamycin & $2.95 \pm 0.64 \dagger$ & $3.39 \pm 1.04 \dagger$ \\
Cefotaxime & $0.08 \pm 0.02$ & $0.34 \pm 0.08$ \\
Ceftizoxime & $0.21 \pm 0.11$ & $0.52 \pm 0.18$ \\
Ceftriaxone & $0.12 \pm 0.04$ & $0.38 \pm 0.23$ \\
N-formimidoyl thienamycin & $0.18 \pm 0.09$ & $0.33 \pm 0.14$ \\
\hline
\end{tabular}

${ }^{*} \mathrm{C} / \mathrm{E}$ results expressed as mean $\pm \mathrm{SD}$.

$\dagger p<0.001$, compared to all other variables.

Table 2. Minimum inhibitory/bactericidal concentrations of investigative isolates

\begin{tabular}{llllll}
\hline & \multicolumn{2}{c}{$\begin{array}{c}\text { SA ATCC } \\
\text { Drug* }\end{array}$} & & \multicolumn{2}{c}{ Hib } \\
\cline { 5 - 6 } \cline { 5 - 6 } \cline { 5 - 6 } & MIC & MBC & & MIC & MBC \\
\hline Ampicillin & & & & 0.1 & 0.3 \\
Nafcillin & 2.0 & 4.0 & & \\
Clindamycin & 0.5 & 1.0 & & \\
Gentamicin & 0.5 & 1.0 & & \\
Chloramphenicol & & & & & \\
Cefotaxime & 1.0 & 2.0 & & 0.01 & 0.03 \\
Ceftizoxime & 1.0 & 2.0 & & 0.01 & 0.03 \\
Ceftriaxone & 1.0 & 2.0 & & 0.01 & 0.03 \\
N-formimidoyl thienamycin & 0.1 & 0.2 & & 1.0 & 2.0 \\
\hline
\end{tabular}

* Drug concentrations in $\mu \mathrm{g} / \mathrm{ml}$. 
Cell-associated killing of $S A$ and Hib by antibiotics. After the initial 30-min incubation, cell control (PMN) mixtures were treated with lysostaphin (SA) or differentially washed (Hib) and contained $5.75 \pm 3.85 \times 10^{3} \mathrm{cfu} / \mathrm{ml}$ of SA and $3.39 \pm 1.24 \times$ $10^{3} \mathrm{cfu} / \mathrm{ml}$ of $\mathrm{Hib}$ in individual assays. Although nearly all cellassociated organisms were intracellular, small numbers of viableappearing extracellular organisms have been seen in identical experiments in the past $(5,6,11,14)$. There was a decrease of $\leq$ $0.5 \mathrm{log}$ in the number of $\mathrm{cfu} / \mathrm{ml}$ in the antibiotic-free PMN reaction mixtures (cell control) over the 4-h incubation for SA and Hib. All data in Figures 1 and 2 are shown as the fraction survival (percent) of SA and Hib in assays with PMNs plus antibiotics compared to parallel $\mathrm{cfu} / \mathrm{ml}$ in tubes with PMNs that did not contain antibiotics at each time point (corrected fraction survival). In the SA assays, all drug concentrations used were equal to the MBC except clindamycin and $\mathrm{N}$-formimidoyl thienamycin. The effect of twice the MBC of clindamycin was similar to the results at the MBC (data not shown), and the higher concentration which is easily acheivable in humans was investigated to evaluate for an enhanced effect. When tested at the same multiples of the MBC, N-formimidoyl thienamycin (MBC, $2 \times$ $\mathrm{MBC}$ ) was found to have activity comparable to third generation cephalosporins (MBC) and less activity than clindamycin (MBC; data not shown). However, the higher concentrations of $\mathrm{N}$ formimidoyl thienamycin $(5 \times \mathrm{MBC})$, which are within the clinically achievable range, demonstrated substantial activity similar to that seen with the lower concentration (MBC) of clindamycin (Fig. 1). In the Hib assays, no effect on Hib viability was seen with ampicillin, cefotaxime, ceftizoxime, ceftriaxone, or $\mathrm{N}$-formimidoyl thienamycin at concentrations equal to the respective MBCs. The concentrations of four to 15 times the $\mathrm{MBC}$ were chosen to demonstrate effect and to represent achievable concentrations in patient compartments.

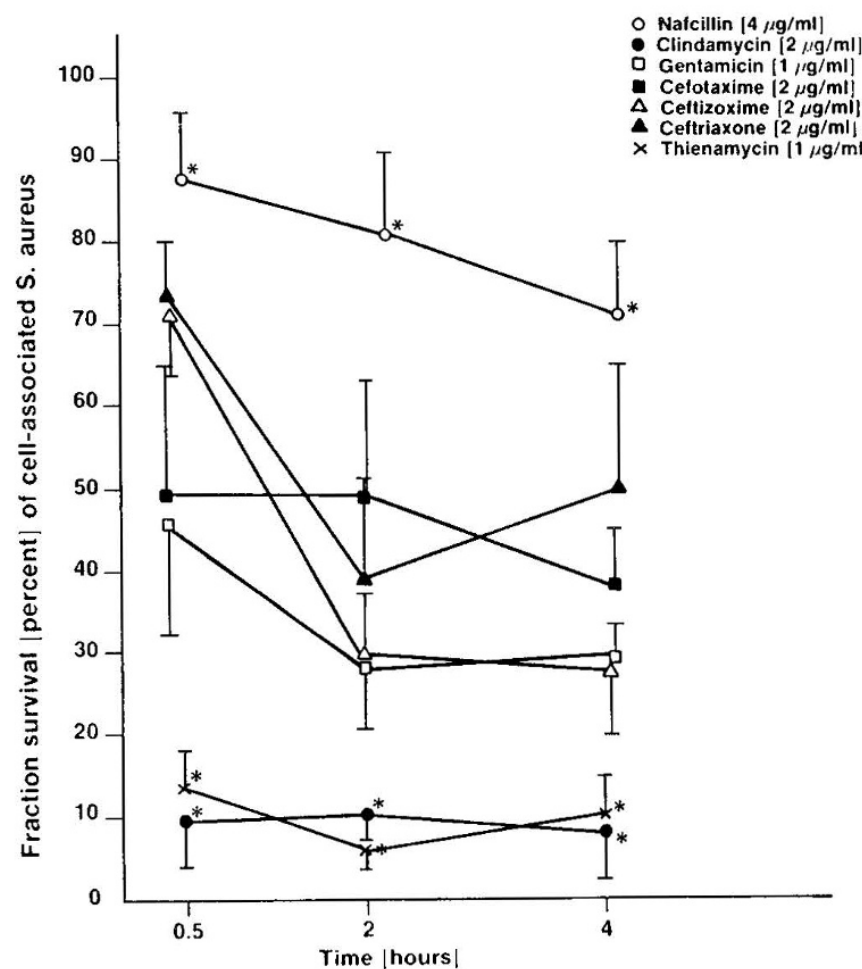

Fig. 1. Fraction survival (percent) of cell-associated SA with antibiotics compared to antibiotic-free cell controls (PMNs) versus time. Values shown represent the mean $\pm \mathrm{SD}(n=6)$ compared to PMN cell control ( $100 \%$ at each time, corrected). Killing of cell-associated SA by PMNs alone was $\leq 0.5 \log$ at each time point. Fraction survival was significantly higher with nafcillin $(4 \mu \mathrm{g} / \mathrm{ml} ; p<0.05)$ and significantly lower with clindamycin $(2 \mu \mathrm{g} / \mathrm{ml} ; p<0.01)$ and $\mathrm{N}$-formimidoyl thienamycin $(1 \mu \mathrm{g} /$ $\mathrm{ml} ; p<0.01)$ compared to other $\beta$-lactam antibiotics.

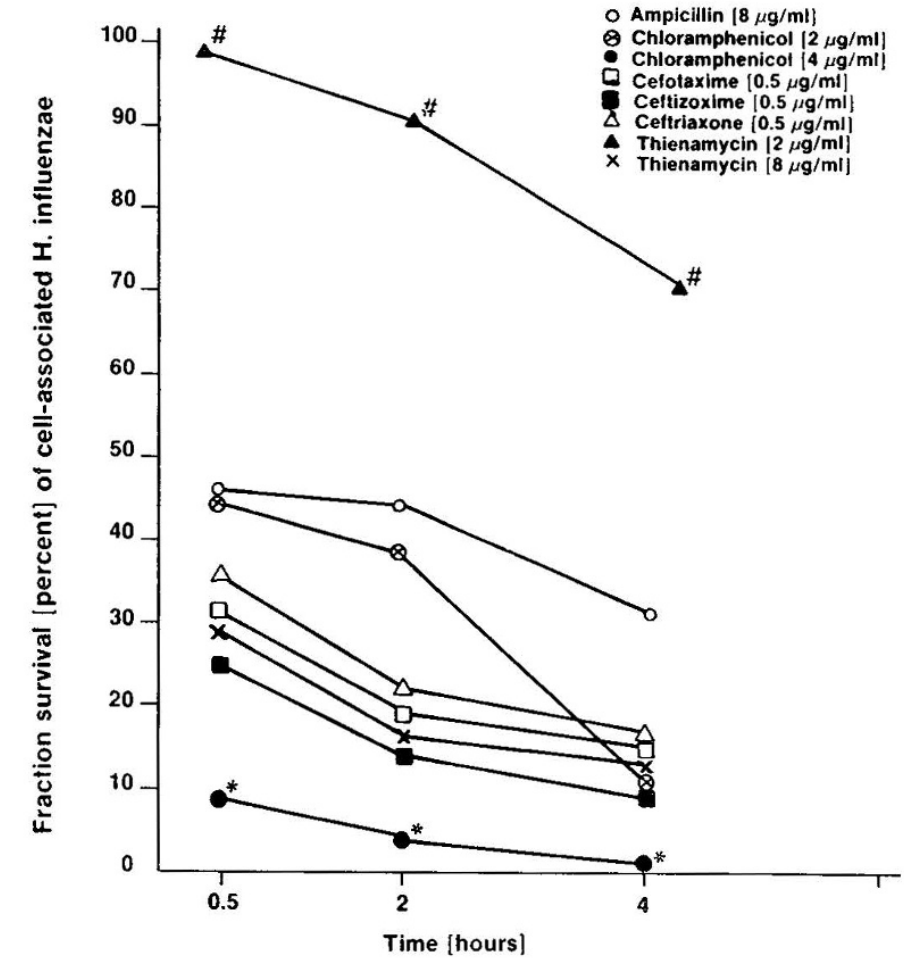

Fig. 2. Fraction survival (percent) of cell-associated Hib with antibiotics compared to antibiotic-free cell controls (PMNs) versus time. Values shown represent the mean $(n=4)$ compared to PMN cell control ( $100 \%$ at each time, corrected). Killing of cell-associated Hib by PMNs alone was $\leq 0.5 \log$ at each time point. Fraction survival was significantly higher for $\mathrm{N}$-formimidoyl thienamycin $(2 \mu \mathrm{g} / \mathrm{ml} ; p<0.05)$ and was similar to other $\beta$-lactam antibiotics at $8 \mu \mathrm{g} / \mathrm{ml} \mathrm{N}$-formimidoyl thienamycin. Fraction survival was significantly lower for chloramphenicol (4 $\mu \mathrm{g} / \mathrm{ml} ; p<0.05$ ) compared to all other antibiotics.

In Figure 1, the effect of antibiotics on cell-associated SA demonstrated a lack of effective killing by nafcillin (fraction survival: $88 \pm 8 \%, 81 \pm 13 \%, 71 \pm 19 \%$ at $0.5,2,4 \mathrm{~h}$, respectively; $p<0.05$, compared to all other antibiotics) and the efficient killing of cell-associated SA by clindamycin (fraction survival: $9.7 \pm 5.1 \%, 10.3 \pm 2.4 \%, 8.1 \pm 5.1 \%$ at $0.5,2,4 \mathrm{~h}$, respectively, $p<0.01$, compared to all drugs except $\mathrm{N}$-formimidoyl thienamycin). The increased killing of cell-associated SA by $\mathrm{N}$-formimidoyl thienamycin (fraction survival: $13.9 \pm 4.1 \%, 7.4$ $\pm 2.2 \%, 9.9 \pm 6.3 \%$ at $0.5,2,4 \mathrm{~h}$, respectively) was significantly greater $(p<0.01)$ than the other $\beta$-lactam drugs and probably reflects the increased susceptibility (MIC/MBC: $0.1 / 0.2 \mu \mathrm{g} / \mathrm{ml}$ ) of SA for the concentration of $\mathrm{N}$-formimidoyl thienamycin in the reaction mixtures $(1 \mu \mathrm{g} / \mathrm{ml} ; 5$ - to 10 -fold higher concentration). This killing, however, was only seen at a concentration five times the MBC of the organism. The killing of cell-associated SA by gentamicin, cefotaxime, ceftizoxime, and ceftriaxone were similar at all times points and was significantly greater then nafcillin $(p<0.05)$ with the exception of ceftriaxone at 0.5 and $4.0 \mathrm{~h}$ ( $p>0.05$; Fig. 1$)$.

In Figure 2, the effect of antibiotics on cell-associated Hib are shown. The excellent penetration of the lipophilic antibiotic, chloramphenicol, in combination with its bactericidal activity against Hib produced significant killing (fraction survival, $8 \mu \mathrm{g}$ / $\mathrm{ml}: 9 \pm 6 \%, 4 \pm 3 \%, 1 \pm 1 \%$ at $0.5,2,4 \mathrm{~h}$, respectively) compared to all other antibiotics ( $p<0.05$, Fig. 2). Of note, the cellassociated killing by chloramphenicol $(2 \mu \mathrm{g} / \mathrm{ml}, \mathrm{MBC}$ concentration) was similar to ampicillin $(8 \mu \mathrm{g} / \mathrm{ml},>20$-fold the MBC) at 0.5 and $2 \mathrm{~h}$; the cell-associated killing was significantly less at 4 h with ampicillin $(22 \pm 7 \%)$ than with $2 \mu \mathrm{g} / \mathrm{ml}$ chloramphenicol $(11 \pm 6 \%, p<0.05)$. The killing of cell-associated Hib by 
cefotaxime, ceftizoxime, and ceftriaxone was significantly greater than ampicillin at all time points ( $p<0.05$; Fig. 2) even at a concentration of $0.5 \mu \mathrm{g} / \mathrm{ml}$ and probably reflected the lower $\operatorname{MBC}(0.03 \mu \mathrm{g} / \mathrm{ml})$ for these antibiotics. A concentration of $8 \mu \mathrm{g} /$ $\mathrm{ml}$ of $\mathrm{N}$-formimidoyl thienamycin was required before comparable killing was observed (Fig. 2). $\mathrm{N}$-formimidoyl thienamycin $(2 \mu \mathrm{g} / \mathrm{ml} ; \mathrm{MBC}-2 \mu \mathrm{g} / \mathrm{ml})$ did not effectively kill cell-associated Hib (fraction survival: $96 \pm 32 \%, 92 \pm 27 \%, 70 \pm 20 \%$ at 0.5 , $2,4 \mathrm{~h}$, respectively) compared to all other antibiotics and probably reflects the degree of penetration into PMNs coupled with a higher MBC compared to the other $\beta$-lactam antibiotics.

\section{DISCUSSION}

The significance of in vitro antibiotic penetration and intracellular killing has some clinical correlates for support $(2,8,9)$. The question of whether or not cell-associated organisms actually occupy an intracellular location has been a criticism of in vitro phagocyte research for several years. In previous experiments, we have performed phase contrast and electron microscopy to demonstrate the intracellular location of $\mathrm{Hib}$ and $\mathrm{SA}$ in this assay system $(5,14)$.

We and others have demonstrated that hydrophilic antibiotics such as penicillin do not penetrate phagocytes and that lipophilic antibiotics such as chloramphenicol and clindamycin penetrate and are concentrated in phagocytes $(5,6,11,16-18)$. The activity of antibiotics that penetrate normal and chronic granulomatous disease PMNs against cell-associated bacteria has been demonstrated in vitro to be significantly greater than antibiotics that are excluded from PMNs $(6,19,20)$. The newer $\beta$-lactam antibiotics, cefotaxime, ceftizoxime, ceftriaxone, and $\mathrm{N}$-formimidoyl thienamycin (Imipenem), are similar to penicillin in their relative inability to penetrate PMNs.

The killing of cell-associated SA was enhanced with clindamycin and not nafcillin, as previously described $(6,11)$. The activity of gentamicin in this situation has been described as poor $(6,11)$ and intermediate in these experiments. It was not comparable to clindamycin. The third generation cephalosporins showed intermediate activity against cell-associated SA that was susceptible to these compounds by MIC/MBC testing. N-formimidoyl thienamycin was, however, found to be very effective in these experiments against SA, but the concentration required was higher in comparison to achievable serum concentrations of the third generation cephalosporins. These observations may be a demonstration of the increased susceptibility of most strains of SA against this antibiotic (21); the MIC/MBC for this strain was less than for the third generation cephalosporins. However, enhanced killing of cell-associated SA was seen only at concentrations five times the MBC. The potential clinical importance of this effect may be seen only in those patients in which higher serum concentrations of $\mathrm{N}$-formimidoyl thienamycin are achieved. There were no significant differences in killing of cellassociated SA by cefotaxime or ceftizoxime; ceftriaxone demonstrated comparable activity but was not significantly greater than nafcillin at 0.5 and $4 \mathrm{~h}$.

The analysis of cell-associated killing of Hib demonstrated again that chloramphenicol is superior in its intracellular activity due at least in part to its penetrating potential. There was increased activity of cefotaxime, ceftizoxime, and ceftriaxone against cell-associated Hib compared to drug free controls. This increased activity probably reflects the marked susceptibility of Hib for these antibiotics. A concentration of ampicillin approximately 26 times the MBC was required to produce killing comparable to $0.5 \mu \mathrm{g} / \mathrm{ml}$ of these antibiotics (approximately 17 times the $\mathrm{MBC}$ ). Of interest, $\mathrm{N}$-formimidoyl thienamycin with a higher MBC $(2.0 \mu \mathrm{g} / \mathrm{ml})$ demonstrated poor killing at $2 \mu \mathrm{g} / \mathrm{ml}$ and required $8 \mu \mathrm{g} / \mathrm{ml}$ (four times the $\mathrm{MBC}$ ) to kill comparable numbers of cell-associated Hib. This lack of significant killing of cell-associated $\mathrm{Hib}$ by an antibiotic that penetrates phagocytes poorly and is at an extracellular concentration equal to the MBC supports the intracellular location of the organisms and the significance of phagocyte penetration in eradicating these organisms.

The issue of intracellular activity of antibiotics is probably multifactorial and effective antimicrobial activity may require a bactericidal drug that is capable of acheiving therapeutic concentrations in the appropriate compartment (joint fluid, cerebrospinal fluid) as well as the ability to penetrate phagocytes in a bioactive form. These data support the importance of both the extracellular concentration of the drug relative to the $\mathrm{MBC}$ of the organism and the intracellular/extracellular concentration ratio as determinants of effectiveness intracellulary.

In summary, we have demonstrated that newer $\beta$-lactam antibiotics do not efficiently penetrate PMNs. The intracellular activity of these antibiotics is directly effected by the susceptibility of the organism and the ability of these antibiotics to penetrate the cell. The clinical significance of intracellular activity of newer $\beta$-lactam antibiotics awaits further experience against susceptible bacteria capable of survival within phagocytic cells.

\section{REFERENCES}

1. Shaffer JM, Kucera CH, Spink WW 1953 The protection of intracellular Brucella against therapeutic agents and the bactericidal action of serum. J Exp Med 97:77-90

2. Holmes B, Quie PG, Windhorst DB, Pollard B, Good RA 1966 Protection of phagocytized bacteria from the killing action of antibiotics. Nature 210:1131-1132

3. Solberg CO 1972 Protection of phagocytized bacteria against antibiotics. A new method for the evaluation of neutrophil granulocyte functions. Acta Med Scand 191:383-387

4. Mandell GL 1973 Interaction of intraleukocytic bacteria and antibiotics. J Clin Invest 52:1673-1679

5. Jacobs RF, Wilson CB, Laxton JG, Haas JE, Smith AL 1982 Cellular uptake and intracellular activity of antibiotics against Haemophilus influenzae type b. J Infect Dis 145:152-159

6. Jacobs RF, Wilson CB 1983 Activity of antibiotics in chronic granulomatous disease leukocytes. Pediatr Res 17:916-919

7. Horwitz MA, Silverstein SC 1983 Intracellular multiplication of Legionnaires' disease bacteria (Legionella pneumophila) in human monocytes is reversibly inhibited by erythromycin and rifampin. J Clin Invest 71:15-26

8. Beam TR 1979 Sequestration of staphylococci at an inaccessible focus. Lancet 2:227-228

9. Lobo MC, Mandell GL 1972 Treatment of experimental staphylococcal infection with rifampin. Antimicrob Agents Chemother 2:195-200

10. McCracken GH, Jr., Nelson JD 1982 The third generation cephalosporins and the pediatric practitioner. Pediatr Infect Dis 1:123-125

11. Jacobs RF, Wilson CB 1983 Intracellular penetration and antimicrobial activity of antibiotics. J Antimicrob Chemother 12:13-20

12. Washington JA, Sutter VL 1980 Dilution susceptibility test: agar and macrobroth dilution procedures. In: Lennette $\mathrm{EH}$, Balows A, Hausler $\mathrm{Jr}$ WJ, Truant JP (eds) Manual of Clinical Microbiology, 3rd ed. American Society for Microbiology, Washington, D.C., pp 453-458

13. Catlin BW 1973 Nutritional profiles of Neisseria gonorrhoeae, Neisseria meningitidis, and Neisseria latamica in chemically defined media and the use of growth requirements for gonococcal typing. J Infect Dis 128:178-194

14. Jacobs RF, Locksiey RM, Wilson CB, Haas JE, Klebanoff SJ 1984 Interaction of primate alveolar macrophages and Legionella pneumophila. J Clin Invest $73: 1515-1523$

15. Snedecor GW, Cochran WG 1967 Statistical Methods. Iowa State University Press, Ames, IA, pp 66-116

16. Prokesch RC, Hand WL 1982 Antibiotic entry into human polymorphonuclear leukocytes. Antimicrob Agents Chemother 21:373-380

17. Johnson JD, Hand WL, Francis JB, Thompson NK, Corwin RW 1980 Antibiotic uptake by alveolar macrophages. J Lab Clin Med 95:429-439

18. Klempner MS, Styrt B 1981 Clindamycin uptake by human neutrophils. J Infect Dis 144:472-479

19. Ezer G, Soothill JF 1974 Intracellular bactericidal effects of rifampicin in both normal and chronic granulomatous disease polymorphs. Arch Dis Child 49:463-466

20. Mandell GL, Vest TK 1972 Killing of intraleukocytic Staphylococcus aureus by rifampin: in vitro and in vivo studies. J Infect Dis 125:486-490

21. Cohn DL, Reimer LG, Reller LB 1982 Comparative in-vitro activity of MK0787 (N-formimidoyl thienamycin) against 540 blood culture isolates. J Antimicrob Chemother 9:183-194 